\title{
Editorial: Spring 2019
}

\section{Per Andersson, Hedvig Skonhoft Johannesen, Sofia Nyström}

Linköping University, Sweden (per.andersson@liu.se, sofia.nystrom@liu.se)

OsloMet - Oslo Metropolitan University, Norway (hjohanne@oslomet.no)

The Nordic Journal of Vocational Education and Training, NJVET, is a forum for the publication of research on vocational and professional education and training, with a particular focus on issues concerning vocational education and training (VET) in the Nordic countries. Our journal is published on behalf of Nordyrk, which is a Nordic network for vocational education and training. The journal has developed over the years, and we have now reached our ninth volume. Next year will mean not only volume 10 of NJVET, but also the 10th anniversary of Nordyrk. This will be celebrated at the Nordyrk conference in Copenhagen in June 2020. This year our VET research community met at Arcada University of Applied Sciences in Helsinki for an interesting and well-organised conference, and next year you are welcome to University College Copenhagen, Denmark, which is hosting the anniversary conference. NJVET encourages researchers who present their work at the Nordyrk conference to develop their papers and submit them for peer-review and publication in our journal.

In this issue we present seven peer-reviewed research articles covering different aspects of vocational education and training in the Nordic countries. There are three articles from Norway, two from Finland, and two from Sweden. To make the findings accessible to a broader audience, we encourage publication in English, and in this issue three of the articles are written in English - one from each of the three countries represented. In addition to this, we have four articles in Nordic languages - two in Norwegian and two in Swedish. It should be noted that also the articles in Nordic languages have a translated title, abstract and key words in English, to make even these texts accessible to some extent to you who are not able to read Norwegian, Swedish, or Danish. 


\section{The seven contributions}

In the first article, Bedriftenes perspektiver og behov når elevene er i yrkesfaglig praksis (The companies' perspectives and needs during vocational education), Anne Breen and Merete C. Rekdahl study collaboration between schools and workplaces in Norwegian vocational education. The authors' scope in the article relates to the perspective of the companies related to VET-students' work-based placements. The emphasis is on the subject vocational in-depth learning in the Norwegian school-based VET, where VET students participate in work-based placements. The results show that the VET students in the study contribute to the recruitment in the workplaces, they enhance workplace learning and subsequently motivate mentors during placements.

The second article, Student engagement at the beginning of vocational studies, by Satu Niittylahti, Johanna Annala and Marita Mäkinen, is situated in Finnish vocational education and concerns student engagement in relation to uncertainty about career choices. The authors draw their analysis from mixed methods data from first-year students, consisting of a survey followed up by qualitative interviews. The results indicate that in order to ensure student engagement early in the course of studies there should be a more collective approach in vocational education and training. Further, the findings show that in order to promote student engagement in vocational education and training, the social components should comprise peer learning, collaborative projects with friends and fellow students, supported by vocational teachers and adults in collaborative effort.

The third article is from Norway and concerns writing practices in vocational education. In To kontekster - to skrivepraksiser? Skriving $i$ skole og bedrift $i$ fag- og yrkesopplæringen (Two contexts - two writing practices? Writing in school and enterprises of Technical and Vocational Education and Training), Ellen Beate Hellne-Halvorsen analyses literacy and writing practices in Norwegian TVET in a socio-cultural approach with the research question: How is writing practiced in school and enterprise - as similar or as different practices? The findings in the article suggest that the writing practices in school and in enterprises primarily mediate learning outcomes from the school-based curriculum in assessment of vocational specific terminology and argumentation. Teachers and trainers in this study do not seem to relate to the writing competence requirements in enterprises. Subsequently generic and trans-contextual writing skills appear not to be prioritized in this sample in Norwegian technical and vocational education and training.

In the fourth contribution, Eva Eliasson examines 'didactic principles in health care teachers' description of their teaching practices, and how these principles were intertwined with vocational knowledge.' Her article Att undervisa för utveckling av yrkeskunnande $i$ vård och omsorg (Teaching for development of vocational knowledge in health care) particularly studies the didactical approach of healthcare teachers in Swedish health-care education. The findings in the article show 
that vocational knowledge and didactical knowledge are closely connected. Didactical principles such as dialogue, work relevance, relational environment and language were areas where the health-care teachers served as boundary-crossing role models for the students. The article discusses if the emphasis on femininecoded vocational knowledge is too strong, and raises questions whether reading and writing are too little focused the health-care teachers' teaching practices.

The fifth article puts focus on Swedish vocational teachers' work with their students' work-based learning. In A recruiter, a matchmaker, a firefighter: Swedish vocational teachers' relational work, Åsa Mårtensson, Per Andersson and Sofia Nyström analyse the character of the relational work carried out by VET teachers concerning work-based learning (WBL). The study employs a situated learning perspective, and particularly the concepts of community of practice, broker, and boundary crossing. The findings describe and analyse three central parts of VET teachers' relational work with WBL: recruiting workplaces for WBL, matchmaking between students and workplaces, and 'firefighting' to prevent and deal with problems that could occur during the WBL periods. In this work, the VET teachers cross the 'blurred boundaries' between school and working life and strive to create a good work-based learning environment for all students.

Birgit Schaffar discusses a more general concern in her article - namely the notion of competence, which is central in the discourse of vocational education and training. In Svårigheter $i$ att definiera begreppet kompetens (Difficulties in defining the notion of competence) she highlights the notion of 'competence' combines a psychological meaning of an inner disposition, and a sociological meaning as a category organising tasks and power-relations in institutions. Schaffar also discusses how the complex etymology of the notion could explain different layers of possible usages and different ontological and epistemological assumptions that arise from them.

In the last and seventh article of this issue - Educational time-out between a rock and a hard place: Vocational students in search of coherent life narratives, Kaja Reegård analyses how students in Norwegian vocational education justify a gap year as a period of time-out before they have to make choices for their (educational) future.This rather unplanned period of time-out among VET students could be compared to how the international literature describes the gap year as a way for privileged students of getting ahead in the competition for access to elite universities.

\section{Changes in the editorial group}

This is the last issue of NJVET where associate professor Sofia Nyström from Linköping University, Sweden, is part of the editorial group as an associate editor. Sofia Nyström will step down from this position, but will remain a member of our editorial board. Sofia will be replaced by associate professor Song-ee Ahn 
from the Department of Behavioural Sciences and Learning at Linköping University. In addition to this, we are also happy to announce that the editorial group will be strengthened with a third associate editor. Associate professor Arnt Louw from the Danish Centre for Youth Research at Aalborg University will join the editorial group, which means that three Nordic countries will be represented in the group from now on. We are glad that Song-ee Ahn and Arnt Louw have accepted the role as associate editors, and their contributions will be most valuable for the development of our journal. 